\title{
PENGARUH EFEKTIVITAS BELAJAR SISWA TERHADAP HASIL BELAJAR SISWA MATA PELAJARAN IPS KELAS VII SMP NEGERI 5 PANJI SITUBONDO SEMESTER GENAP TAHUN PELAJARAN 2015/2016
}

\section{Khusnul Khotimah}

Dassucik

\begin{abstract}
Abstrak: Sistem kurikulum sekarang ini pelaksanaannya tidak lepas dari kegiatan efektivitas pada siswa atau melibatkan langsung siswa dalam suatu pembelajaran, siswa dapat dilibatkan secara aktif, karena mereka adalah pusat dari kegiatan pembelajaran dan pembentukan kompetensi. Siswa harus dilibatkan dalam tanya jawab yang terarah dan mencari pemecahan terhadap berbagai masalah pembelajaran. Peserta didik harus didorong untuk menafsirkan informasi yang diberikan oleh guru, sampai informasi tersebut dapat diterima oleh akal sehat. Tujuan penelitian ini adalah untuk mengetahui pengaruh efektivitas belajar terhadap hasil belajar siswa pada mata pelajaran IPS kelas VII SMP Negeri 5 Panji Situbondo semester genap tahun pelajaran 2015/2016. Dari hasil penelitian yang diperoleh dengan menggunakan rumus analisis variansi garis regresi, nilai $\mathrm{Ry}(1,2)$ empiric sebesar 0,60017, yang apabila dikonsultasikan dengan $r$-table dengan $\mathrm{N}$ sebanyak 100 responden dan taraf signifikansi 5\%, diperoleh 0,195. Penghitungan tersebut dimaksudkan untuk membuktikan hipotesa kerja mayor dengan menggunakan uji signifikansi. Dari hasil penghitungan analisis variansi garis regresi diperoleh $F$ reg sebesar 27,30494. Dan apabila dikonsultasikan dengan $F$ tabel untuk $\mathrm{db}_{1}=2$ dan $\mathrm{db}_{2}=97$ dengan taraf signifikansi 5\%, diperoleh 3,0902. Dengan demikian, dari hasil perhitungan tersebut, menunjukkan bahwa nilai $F$ reg melebihi nilai $F$ tabel. Berdasarkan hasil analisa data tersebut, maka hipotesa kerja mayor yang berbunyi "ada pengaruh efektivitas belajar siswa terhadap hasil belajar siswa mata pelajaran IPS kelas VII semester genap SMP Negeri 5 Panji Situbondo semester genap tahun pelajaran 2015/2016" diterima. Selanjutnya, diperoleh tingkat efektivitas garis regresi sebesar $36,01972 \%$. Ini berarti bahwa sumbangan dari prediktor adalah sebesar $36,01972 \%$, sedangkan prediktor lain yang tidak diteliti memberikan sumbangan sebesar 63,98828\%. Sumbangan efektif (SE) prediktor efektivitas belajar siswa di sekolah $\left(\mathrm{X}_{1}\right)$ terhadap kriterium hasil belajar (Y) adalah sebesar 17,02444\%, sedangkan sumbangan efektif (SE) prediktor efektivitas belajar siswa di rumah $\left(\mathrm{X}_{2}\right)$ terhadap kriterium hasil belajar (Y) adalah sebesar 18,99528\%. Hal ini menunjukkan bahwa efektivitas belajar di rumah lebih berpengaruh terhadap hasil belajar siswa dibandingkan efektivitas belajar di sekolah.
\end{abstract}

Kata Kunci : Efektivitas Belajar dan Hasil Belajar Siswa

\section{PENDAHULUAN}

\section{Latar Belakang Masalah}

Pendidikan dipandang sebagai cara yang tepat untuk membentuk sumber daya manusia yang berkualitas untuk mendukung tercapainya tujuan pembangunan nasional. Melalui pendidikan, manusia mendapatkan pengetahuan, keterampilan, nilai, dan sikap sehingga dapat berpikir lebih sistematis, rasional, dan kritis terhadap permasalahan yang dihadapi (Sudjana, 2012:60). 
Perubahan dan perkembangan aspek kehidupan perlu ditunjang oleh kinerja pendidikan yang bermutu tinggi. Pendidikan yang berkualitas sangat diperlukan untuk mendukung terciptanya manusia yang cerdas serta mampu bersaing di era globalisasi. Pendidikan mempunyai peranan yang sangat besar dalam membentuk karakter, perkembangan ilmu dan mental seorang anak, yang nantinya akan tumbuh menjadi seorang manusia dewasa yang akan berinteraksi dan melakukan banyak hal terhadap lingkungannya, baik secara individu maupun sebagai makhluk sosial (Purwanto, 2010:45)

Secara total, pendidikan merupakan suatu sistem yang memiliki kegiatan cukup kompleks, meliputi berbagai komponen yang berkaitan satu sama lain. Jika menginginkan pendidikan terlaksana secara teratur, berbagai elemen (komponen) yang terlibat dalam kegiatan pendidikan pelu dikenali. Peran serta orang tua dalam membantu proses belajar anak sangat diperlukan. Hal ini disebabkan orang tua merupakan salah satu pihak yang paling bertanggung jawab terhadap keberhasilan proses pendidikan anaknya yang mempunyai pengaruh sangat besar dalam menunjang hasil belajar anak. Dalam hal ini, orang tua dituntut untuk memenuhi kebutuhan hidup anak, seperti membimbing, mengarahkan, serta mendidiknya.

Untuk meningkatkan mutu pendidikan diperlukan pembaharuan dalam proses pembelajaran yang mudah dipahami dan dilakukan oleh guru, agar proses belajar mengajar dapat berjalan secara efektif dengan harapan dapat meningkatkan kualitas pendidikan, khususnya dalam peningkatan hasil belajar siswa. Pembaharuan pendidikan tersebut tidak dapat dilakukan oleh satu komponen saja, melainkan harus ada kerjasama dengan komponen lain, sehingga dalam meningkatkan kualitas pendidikan merupakan tanggung jawab bersama antara guru, siswa, masyarakat, dan seluruh komponen pendidikan.

Efektivitas adalah penunjukan taraf pencapaian sesuatu, dalam hal ini efektivitas dapat dilakukan dengan melaksanakan tahap pemanasan, bereksplorasi, memperkenalkan, mengaitkan, menyajikan standar materi, menggunakan metode yang paling tepat dan bervariasi, konsolidasi pembelajaran, pembentukan kompetensi, sikap, dan perilaku melalui penilaian formatif yang sesuai (Mansyur, 2012:90)

Efektivitas merupakan suatu tahapan atau proses dalam upaya mencapai tujuan yang telah ditetapkan. Proses belajar mengajar merupakan kegiatan yang sangat kompleks. Oleh sebab itu, dapat berlangsung secara efektif dan efisien jika telah berbentuk komunikasi antara pendidik dan anak didik, baik di dalam kelas maupun di rumah (Mansyur, 2012:90)

Kesuksesan peserta didik sangatlah ditentukan oleh guru yang dapat membimbingnya dalam belajar serta penguasaan sejumlah kompetensi tertentu. Aspek psikologis menunjukkan kenyataan bahwa peserta didik pada umumnya memiliki taraf perkembangan yang berbeda, yang menuntut materi yang berbeda pula. Selain itu, aspek psikologis menunjukkan pada kenyataan bahwa proses belajar itu sendiri mengandung variasi, seperti belajar keterampilan motorik, belajar konsep, belajar sikap, dan seterusnya (Mulyasa, 2011:188). Diharapkan siswa mendapatkan pengetahuan semaksimal mungkin. Dan hasil belajar yang lebih tinggi daripada pengetahuan adalah pemahaman (Sudjana, 2012:24).

Tujuan sebagai arah dari proses belajar mengajar pada hakikatnya adalah rumusan tingkah laku yang diharapkan dapat dikuasai oleh siswa setelah menerima atau menempuh belajarnya. Bahan, alat, metode akan bermuara pada penilaian, yaitu upaya atau tindakan untuk mengetahui sejauh mana tujuan yang telah ditetapkan tercapai atau tidak. Dengan kata lain, penilaian berfungsi sebagai alat untuk mengetahui keberhasilan proses dan hasil belajar siswa.

Dalam proses pembelajaran, siswa dapat dilibatkan secara aktif karena mereka adalah pusat dari kegiatan pembelajaran dan pembentukan kompetensi. Siswa harus dilibatkan dalam tanya jawab yang terarah dan mencari pemecahan terhadap berbagai 
masalah pembelajaran. Peserta didik harus didorong untuk menafsirkan informasi yang diberikan oleh guru, sampai informasi tersebut dapat diterima oleh akal sehat. Melalui pembelajaran yang efektif dan bermakna, kompetensi dapat diterima dan tersimpan lebih baik, karena dapat diterima dan diserap serta mudah dimengerti oleh siswa (Mansyur, 2012:90).

Hasil belajar siswa adalah pencapaian dari kegiatan belajar yang telah dilakukan dan merupakan bentuk perumusan akhir yang diberikan oleh guru untuk melihat samai dimana kemampuan siswa yang dinyatakan dalam bentuk simbol, angka, huruf maupun kalimat yang dapat mencerminkan hasil yang telah dicapai. Namun untuk mendapatkan hasil belajar yang baik bukanlah hal yang mudah, tetapi membutuhkan usaha yang optimal (Sudjana, 2012:56).

Hasil belajar menjadi faktor penting dalam memenuhi keinginan siswa sebagai pembelajar. Hasil belajar menjadi tolok ukur keberhasilan siswa sebagai pembelajar, yang mana hal tersebut dipengaruhi oleh banyak faktor, diantaranya adalah efektivitas belajar siswa. Teori ini pun didukung oleh pendapat Purwanto (2010:28), bahwa efektivitas berarti keterpaduan, hasil guna, menunjang tujuan. Sesuatu dikatakan efektif apabila tepat pada sasaran yang dituju.

Penelitian mengenai efektivitas belajar siswa pernah dilakukan sebelumnya. Penelitian yang dilakukan oleh Kusnadi yang berjudul "Pengaruh Efektivitas Belajar Siswa Terhadap Hasil Belajar Peserta Didik Kelas VIII SMP Negeri 2 Tlogosari Bondowoso" menyebutkan bahwa efektivitas belajar siswa berpengaruh sebesar $42 \%$ terhadap hasil belajar siswa. Selain itu penelitian Kuswanto (2011) yang berjudul "Korelasi Efektivitas Belajar Siswa dengan Hasil Belajar Mata Pelajaran IPS Siswa Kelas VII SMP Negeri 2 Mlandingan Tahun Pelajaran 2010/2011" menyimpulkan bahwa efektivitas belajar siswa mempunyai hubungan yang tinggi dengan hasil belajarnya pada mata pelajaran IPS.
Berdasarkan uraian di atas, akan dilaksanakan sebuah penelitian berjudul "Pengaruh Efektivitas Belajar Siswa Terhadap Hasil Belajar Mata Pelajaran IPS Siswa Kelas VII SMP Negeri 5 Panji Situbondo Semester Genap Tahun Pelajaran 2015/2016".

\section{Rumusan Masalah}

Rumusan masalah yang diajukan dalam penelitian ini adalah sebagai berikut.

1. Masalah Mayor

Adakah pengaruh efektivitas belajar terhadap hasil belajar mata pelajaran IPS siswa kelas VII SMP Negeri 5 Panji Situbondo tahun pelajaran $2015 / 2016$ ?

\section{Masalah Minor}

a. Adakah pengaruh efektivitas belajar di sekolah terhadap hasil belajar mata pelajaran IPS siswa kelas VII SMP Negeri 5 Panji Situbondo tahun pelajaran 2015/2016?

b. Adakah pengaruh efektivitas belajar di rumah terhadap hasil belajar mata pelajaran IPS siswa kelas VII SMP Negeri 5 Panji Situbondo tahun pelajaran 2015/2016?

\section{KAJIAN TEORI}

\section{Efektivitas Belajar}

Sudjana (2012:57-60) mengatakan bahwa proses belajar mengajar dikatakan efektif apabila menunjukkan kriteria sebagai berikut.

a. Konsistensi kegiatan belajar mengajar dengan kurikulum

b. Keterlaksanaan oleh guru

c. Keterlaksanaan oleh siswa

d. Keaktifan para siswa dalam kegiatan belajar

e. Interaksi antara guru dan siswa

f. Kemampuan dan keterampilan guru dalam mengajar

g. Kualitas hasil belajar mengajar yang dicapai oleh siswa. 


\section{Hasil Belajar}

Menurut Prasetyo (2008:24), hasil belajar adalah nilai ketercapaian siswa dalam memperoleh kemampuan dasar setelah kegiatan belajar mengajar berlangsung dan dapat dilihat dari hasil ulangan dan nilai ujian akhir semester.

\section{METODE PENELITIAN}

\section{Rancangan Penelitian}

Rancangan penelitian ini adalah ex post facto. Menurut Karlinger (dalam Sukardi, 2008:165), penelitian ex post facto merupakan penelitian dimana variabelvariabel bebas telah terjadi secara alamiah ketika peneliti mulai mengamati variabel terikat dalam sautu penelitian. Sukardi (2008:165) menambahkan bahwa suatu penelitian disebut ex post facto, karena para peneliti berhubungan dengan variabelvariabel yang telah terjadi dan peneliti tidak perlu memberikan perlakuan terhadap variabel yan diteliti.

\section{Lokasi Penelitian}

Penelitian ini dilaksanakan selama satu bulan di SMP Negeri 5 Panji Kabupaten Situbondo. Lokasi penelitian tersebut ditentukan dengan menggunakan metode purposive, yaitu penentuan lokasi penelitian secara disengaja oleh peneliti.

\section{Responden Penelitian}

Penelitian ini menggunakan metode penentuan responden proportional random sampling dengan teknik undian. Dari jumlah siswa kelas VII sebanyak 110 siswa yang terdiri dari siswakelas VII-A, VII-B, dan VII-C, yang kemudian diambil 100 siswa siswa kelas VII SMP Negeri 5 Panji Situbondo semester genap tahun pelajaran $2015 / 2016$. Adapun penghitungan jumlah responden penelitian ini adalah sebagai berikut.
Tabel Jumlah Responden Penelitian

\begin{tabular}{|c|c|c|c|}
\hline No. & Kelas & Populasi & $\begin{array}{c}\text { Sampel } \\
\text { (Jumlah } \\
\text { Responden } \\
\text { Tiap Kelas) }\end{array}$ \\
\hline 1 & VII-A & 37 siswa & $\begin{array}{l}=\frac{37}{110} \times 100 \\
=34 \text { siswa }\end{array}$ \\
\hline 2 & VII-B & 37 siswa & $=\frac{37}{110} \times 100$ \\
$=34$ siswa \\
\hline 3 & VII-C & 36 siswa & $=\frac{37}{110} \times 100$ \\
\hline & & 110 Siswa & \\
\hline
\end{tabular}

\section{Teknik Pengumpulan Data}

Adapun teknik pengumpulan data yang digunakan dalam penelitian ini adalah sebagai berikut.

\section{a. Angket}

Menurut Faisal (2009:122), angket adalah suatu alat pengumpulan data berisi daftar pertanyaan secara tertulis yang diajukan kepada subjek/responden penelitian. Dalam penelitian ini, peneliti menggunakan angket langsung dan tertutup untuk memperoleh data efektivitas belajar siswa di sekolah dan di rumah. Pengumpulan data melalui angket ini dilakukan dengan tatap muka dalam ruang kelas.

\section{b. Dokumenter}

Menurut Arikunto (2009:187), teknik dokumenter digunakan untuk mencari data mengenai variabel-variabel yang diteliti melalui catatan, transkrip, buku, surat kabar, majalah, prasasti, legger, dan agenda. Peneliti menggunakan teknik dokumenter untuk memperoleh data daftar nama siswa kelas VII SMP Negeri 5 Panji Situbondo semester genap tahun pelajaran 2015/2016 serta daftar nilai ulangan harian mereka pada mata pelajaran IPS. 


\section{Teknik Pengolahan Data}

Setelah data terkumpul melalui berbagai metode pengumpulan data di atas, selanjutnya dilakukan pengolahan data melalui tahapan-tahapan berikut ini.

\section{a. Editing}

Editing merupakan pemeriksaan terhadap kelengkapan data yang telah terkumpul.

\section{b. Coding}

Coding merupakan langkah mengklasifikasikan data dalam kategorikategori dengan memberikan kode untuk tiap item pertanyaan dari variabel-variabel yang terdapat dalam angket. Pemberian kode ini dimaksudkan untuk memudahkan proses analisis data. Dalam penelitian ini, coding akan dilakukan dengan cara memberikan angka atau skor pada jawaban responden. Adapun skor pada responden yang digunakan pada tiap-tiap item jawaban dalam angket tertutup adalah sebagai berikut.

1) Jawaban opsi a, diberi skor 3

2) Jawaban opsi b, diberi skor 2

3) Jawaban opsi c, diberi skor 1

c. Tabulasi

Setelah dilakukan editing dan coding, langkah selanjutnya adalah melakukan tabulasi, yaitu memasukkan dan mengisi skor tiap item jawaban responden ke dalam tabel.

\section{Teknik Analisis Data}

Data penelitian ini akan dianalisis secara statistik dengan menggunakan teknik analisis regresi ganda dengan dua prediktor. Adapun langkah-langkah analisis data dengan teknik analisis regresi ganda adalah sebagai berikut.

\section{a. Mencari Koefisien Korelasi Ganda}

Untuk mencari atau menghitung tingkat hubungan antara variabel terikat (kriterium) dengan variabel-variabel bebas (prediktor), dapat menggunakan rumus koefisien korelasi ganda sebagai berikut.

$R_{y(1,2)}=\sqrt{\frac{a_{1} \sum x_{1} y+a_{2} \sum x_{2} y}{\sum y^{2}}}$

Keterangan

$R_{y(1,2)}=$ koefisien korelasi antara prediktor dengan kriterium

$a_{1}=$ koefisien prediktor $\mathrm{X}_{1}$ (efektivitas belajar siswa di sekolah)

$a_{2}=$ koefisien prediktor $\mathrm{X}_{2}$ (efektivitas belajar siswa di rumah)

$\sum x_{1} y=$ jumlah perkalian antara $\mathrm{X}_{1}$ dengan

$\sum x_{2} y=\underset{\mathrm{Y}}{\text { jumlah }}$ perkalian antara $\mathrm{X}_{2}$ dengan

\section{b. Analisis Variansi Garis Regresi}

Analisis variansi garis regresi ini digunakan untuk mengetahui ada atau tidaknya pengaruh prediktor berupa efektivitas belajar siswa di rumah dan di sekolah secara serempak terhadap kriterium hasil belajar IPS, dengan menggunakan rumus:

$F_{\text {reg }}=\frac{R^{2}(N-m-1)}{m\left(1-R^{2}\right)}$

Keterangan

$R^{2}=R_{y}(1,2)$ dikuadratkan

$N=$ banyaknya data

$m$ = banyaknya prediktor (variabel bebas).

Untuk mengetahui ada atau tidaknya pengaruh antara variabel-variabel bebas terhadap variabel terikat, perlu membandingkan nilai $F_{\text {reg }}$ dengan $F$ tabel dengan taraf signifikansi $5 \%$ dengan ketentuan sebagai berikut. 
1) Jika $F_{\text {reg }}>F_{\text {tabel }}$, maka ada pengaruh yang signifikan $\mathrm{X}_{1}$ dan $\mathrm{X}_{2}$ terhadap $\mathrm{Y}$.

2) Jika $F_{\text {reg }}<F_{\text {tabel }}$, maka tidak ada pengaruh yang signifikan $\mathrm{X}_{1}$ dan $\mathrm{X}_{2}$ terhadap Y.

\section{c. Efektivitas Garis Regresi}

Efektivitas garis regresi (EGR) digunakan untuk mengetahui seberapa besar pengaruh $\mathrm{X} 1$ dan $\mathrm{X} 2$ terhadap $\mathrm{Y}$ dengan cara membandingkan jumlah kuadrat regresi (JK reg) dengan jumlah kuadrat total (JK total).

$\mathrm{EGR}=\frac{J K_{\text {reg }}}{J K_{\text {total }}} \times 100 \%$

$J K_{r e g}=a_{1} \sum x_{1} y+a_{2} \sum x_{2} y$

$J K_{\text {total }}=\sum y^{2}$

\section{d. Sumbangan Efektif}

Sumbangan efektif (SE) digunakan untuk mengetahui besar pengaruh masingmasing variabel bebas (prediktor) terhadap variabel terikat (kriterium).

$\mathrm{SE} \% \mathrm{X}_{1}=\frac{a_{1} \sum x_{1} y}{J K_{\text {reg }}} \times 100 \%$

$\mathrm{SE} \% \mathrm{X}_{2}=\frac{a_{1} \sum x_{2} y}{J K_{\text {reg }}} \times 100 \%$

\section{HASIL PENELITIAN}

\section{Persamaan Garis Regresi}

Persamaan garis regresi berganda ditentukan dengan menggunakan metode skor deviasi. Dari hasil penghitungan, diperoleh persamaan garis regresi berganda adalah sebagai berikut.

$$
Y=1,23849 X_{1}+1,48082 X_{2}+14,80506
$$

Dari persamaan garis regresi berganda di atas, diketahui koefisien regresi $\mathrm{X}_{1}$ dan $\mathrm{X}_{2}$ bernilai positif. Hal ini menunjukkan apabila prediktor $\mathrm{X}_{1}$ atau $\mathrm{X}_{2}$ mengalami peningkatan, maka kriterium $\mathrm{Y}$ juga akan mengalami peningkatan.

\section{Koefisien Korelasi Ganda}

Untuk mengetahui sejauh mana hubungan antara efektivitas belajar terhadap hasil belajar siswa pada mata pelajaran IPS, dilakukan penghitungan koefisien korelasi ganda sebagai berikut.

$$
\begin{aligned}
& R_{y(1,2)}=\sqrt{\frac{a_{1} \sum x_{1} y+a_{2} \sum x_{2} y}{\sum y^{2}}} \\
& R_{y(1,2)}=0,60017 \\
& R_{y(1,2)}{ }^{2}=0,36020
\end{aligned}
$$

\section{Analisis Variansi Garis Regresi}

$$
F_{\text {reg }}=\frac{R^{2}(N-m-1)}{m\left(1-R^{2}\right)}
$$

$F_{\text {reg }}=27,30494$

Dengan $d b_{1}=m=2$ dan $d b_{2}=N-m$ $-1=97$, diperoleh nilai $F$ tabel $=3,0902$. Dengan memperhatikan nilai $F$ reg dan $F$ tabel, diketahui bahwa $F_{\text {reg }}>F_{\text {tabel. }}$ Hal ini berarti bahwa ada pengaruh yang signifikan prediktor efektivitas belajar terhadap kriterium hasil belajar siswa pada mata pelajaran IPS.

\section{Efektivitas Garis Regresi (EGR)}

Untuk mengetahui besar pengaruh efektivitas belajar di sekolah bersama-sama dengan efektivitas belajar di rumah terhadap hasil belajar siswa pada mata pelajaran IPS, dipaparkan hasil penghitungan efektivitas garis regresi berikut ini.

$$
\begin{aligned}
& J K_{\text {total }}=6129,00 \\
& J K_{\text {reg }}=2207,64850 \\
& \mathrm{EGR}=\frac{J K_{\text {reg }}}{J K_{\text {total }}} \times 100 \%=\mathbf{3 6 , 0 1 9 7 2 \%}
\end{aligned}
$$


Dengan demikian, dapat diketahui bahwa efektivitas belajar berpengaruh sebesar 36,02\% terhadap hasil belajar siswa pada mata pelajaran IPS. Sedangkan sisanya sebesar 63,98\% dipengaruhi oleh faktor lain yang tidak diteliti pada penelitian ini.

\section{Sumbangan Efektif (SE)}

a. Sumbangan Efektif (SE) $\mathrm{X}_{1}$ terhadap Y

$$
\begin{aligned}
& \text { SE\% } \mathrm{X}_{1}=\frac{a_{1} \sum x_{1} y}{J K_{\text {reg }}} \times 100 \% \\
& \text { SE\% } \mathrm{X}_{\mathbf{1}}=\mathbf{1 7 , 0 2 4 4 4 \%} \\
& \text { SE\% } \mathrm{X}_{\mathbf{1}}=\mathbf{1 7 , 0 2 \%}
\end{aligned}
$$

b. Sumbangan Efektif (SE) $\mathrm{X}_{2}$ terhadap Y

$$
\begin{aligned}
& \text { SE\% } \mathrm{X}_{2}=\frac{a_{1} \sum x_{2} y}{J K_{\text {reg }}} \times 100 \% \\
& \text { SE\% } \mathrm{X}_{\mathbf{2}}=\mathbf{1 8 , 9 9 5 2 8 \%} \\
& \text { SE\% } \mathrm{X}_{\mathbf{2}}=\mathbf{1 9 , 0 0 \%}
\end{aligned}
$$

Berdasarkan hasil penghitungan sumbangan efektif masing-masing prediktor terhadap kriterium, diketahui bahwa sumbangan efektif $\mathrm{X}_{1}$ terhadap $\mathrm{Y}$ adalah sebesar $17,02 \%$ dan sumbangan efektif $X_{2}$ terhadap Y adalah sebesar $19,00 \%$. Hal ini berarti bahwa efektivitas belajar siswa di sekolah berpengaruh sebesar 17,02\% terhadap hasil belajar pada mata pelajaran IPS. Sedangkan efektivitas belajar siswa di rumah berpengaruh sebesar 19,00\% terhadap hasil belajar pada mata pelajaran IPS.

\section{KESIMPULAN}

Berdasarkan hasil penelitian dan pembahasan, penelitian ini dapat disimpulkan bahwa,

a. Simpulan Mayor

Ada pengaruh yang signifikan sebesar $36,02 \%$ efektivitas belajar terhadap hasil belajar mata pelajaran IPS siswa kelas VII SMP Negeri 5 Panji Situbondo semester genap tahun pelajaran 2015/2016. b. Simpulan Minor

1) Ada pengaruh yang signifikan sebesar $17,02 \%$ efektivitas belajar di sekolah terhadap hasil belajar mata pelajaran IPS siswa kelas VII SMP Negeri 5 Panji Situbondo semester genap tahun pelajaran 2015/2016.

2) Ada pengaruh yang signifikan sebesar $19,00 \%$ efektivitas belajar di rumah terhadap hasil belajar mata pelajaran IPS siswa kelas VII SMP Negeri 5 Panji Situbondo semester genap tahun pelajaran 2015/2016.

\section{DAFTAR PUSTAKA}

Arikunto, S. 2009. Prosedur Penelitian Suatu Pendekatan Praktek. Jakarta: Rineka Cipta.

Faisal. 2009. Strategi Belajar Mengajar. Jakarta: Rineka Cipta.

Mansyur. 2011. Belajar dan Pembelajaran. Jakarta: Rineka Cipta

Mulyasa. 2011. Kurikulum Berbasis Kompetensi; Konsep, Karakteristik, dan Implementasi. Bandung: Remaja Rosdakarya.

Prasetyo. 2008. Psikologi Pendidikan. Jakarta: Rineka Cipta.

Purwanto, N. 2010. Kurikulum dan Pembelajaran. Bandung: Alfabeta.

Sudjana, N. 2012. Penilaian Hasil Proses Belajar Mengajar. Bandung: Remaja Rosdakarya.

Sukardi. 2008. Metodologi Penelitian. Bandung: Alfabeta. 